\title{
Trends of organizational branding strategies- systematic review and research agendas
}

\author{
Debebe Alemu* ; Shimelis Zewdie
}

Management Department, Business and Economics College, Jimma University, Ethiopia

*To whom correspondence should be addressed: debealex2@gmail.com

\begin{tabular}{|l|l|l|l|l|}
\hline DOI: & Received: & Revised: & Accepted: & Published: \\
10.22437/ppd.v9i6.15294 & 27.10 .2021 & 25.02 .2022 & 27.02 .2022 & 28.02 .2022 \\
\hline
\end{tabular}

\begin{abstract}
s
Branding is among the activities that seek new ways to balance competition in the business environment to sustain organizational competitive advantage. Hence, this study aims to identify how the concept has been considered in the literature and its evolution in the marketing literature. To achieve the objectives of the systematic study review was conducted from 2010 to 2021 years and identified 98 articles. The collected data were documented in Microsoft Word and retained in Mendeley referencing software. The study revealed that brand and product management lacks conceptual clarity, which influences their measurement and subsequently their management. The review also demonstrates as economic, identity, consumer-based, personality, relational, community, cultural, and sensory approaches, respectively, are the respective evolutions of the concepts.
\end{abstract}

Keywords: Branding, Brand management, Brand strategies, Systematic review

JEL Classification: G24, M13, O15

\section{INTRODUCTION}

Within this competitive business environment, unique means are expected from the organization to survive. It shows no longer a firm's ownership of resources and capabilities that matter but rather how it aligns with customer needs and differentiates in the market (Tajeddini \& Ratten, 2020). The undefined and changeable customer preferences and needs in the business environment (Chan et al. 2019) forced organizations to develop and maintain product usefulness (Bhuiyan, 2011 \& Gupta, 2015) through differences in production methods, features, quality, and branding (Dirisu et al. 2013).

Also, Alano et al. (2015), Choi \& Lee (2019), Tijssen et al. (2019) detailed that currently, introducing a new product is the best means of achieving differentiation and enhancing identity in a business environment. Despite this, existing researchers focus on conceptualizing brand equity (Chen et al. 2016; Brodie et al. 2017), the role and importance of brands from the firm and consumer perspective (Shaari, \& Hussin, 2012; Kanagal, 2015; Aksoy, 2017).

Since this new form of economy is associated with globalization, the proliferation of services, fragmentation, the breakdown of boundaries, liberalization, and 
democratization based on the foremost result of digitalization, brands are becoming more important for all stakeholders and even for national economies of those brands. In this respect, with the higher level of competitiveness and interrelations, businesses compete to create more powerful brands to support their national economies in worldwide markets. Nevertheless, the growing national economies with more valuable brands accepted by global consumers are more powerful than others.

Besides, managing the product or service is expected from the concerned body of the organization (Aurich et al. 2010) as well as the product or services should be supported by having a unique and strong brand that brings a notable reputation and good image to its organization (Pinar et al. 2016). However, the products or services offered by organizations should get attention from the customers (Younus et al., 2015) to achieve the aimed performance.

The concept of branding, scope, and potentialities are examined and explored from the middle of the $80 \mathrm{~s}$, both by researchers and practitioners. It shows the availability of a vast pool of perspectives on product brand conceptualization, development, and management. The existence of this wide collection of distinct perspectives thus presents the need for a clear definition and periodic review of existing literature to obtain a clear and updated overview of the field from time to time. Therefore, the review aims to clarify the brand management concept and identify its evolution in the marketing literature.

\section{METHODS}

A systematic literature review was used as a review technique to achieve the basic research questions since it attempts 'to identify, appraise and synthesize all the empirical evidence that meets pre-specified eligibility criteria to answer a given research question' (Munn et al., 2018). Hence, the literature selected for review purposes should fulfill the following inclusion and exclusion criteria (Tables 1 and 2) and the search strategies.

Table 1. Inclusion criteria

\begin{tabular}{|c|c|c|}
\hline No. & Criteria & Reasons for inclusion \\
\hline 1 & Academic publication & Peer-reviewed journal articles \\
\hline 2 & Articles in English & To avoid language barriers \\
\hline 3 & Quantitative / qualitative / conceptual & $\begin{array}{l}\text { To consider both empirical and } \\
\text { conceptual evidence }\end{array}$ \\
\hline 4 & Brand and product management & Topic understudy \\
\hline 5 & Marketing or strategic marketing management & To limit the subject \\
\hline 6 & Journals in the area of product and branding & Area related to the topic under study \\
\hline 7 & $\begin{array}{l}\text { Scopus, Emerald, EBSCO, Wiley Online } \\
\text { Library, and Science Direct Databases }\end{array}$ & The databases reputability \\
\hline
\end{tabular}

Table 2. Exclusion criteria

\begin{tabular}{l|l|l}
\hline No. & Criteria & Reasons for exclusion \\
\hline 1 & Pre-2010 & \begin{tabular}{l} 
Consider the recent articles on the topic \\
\hline 2
\end{tabular} \\
$\begin{array}{l}\text { Organizational branding / Employee } \\
\text { branding }\end{array}$ & $\begin{array}{l}\text { The review is concerned with product } \\
\text { branding }\end{array}$ \\
\hline
\end{tabular}

The search strategies used for all databases were ("Brand" OR "Branding OR Brand management" OR "Branding strategies") AND ("Product" OR "Product 
management") AND ("customers performance") AND ("brand and product management" OR "brand management and customers performance" OR "product management and customers performance" [Title/Abstract/keyword]). Based on the inclusions and exclusions criteria and the search string used as the initial filter, we obtained a total of 2,109 publications. Subsequently, different filters were used, limiting the number of academic publications to 98 studies for review purposes.

The collected data from systematic searches were documented in Microsoft Word, presented in a summary table, and retained the references in the Mendeley referencing software. As summarizing and integrating different studies on a topic or research questions is the purpose of a systematic review (Tranfield et al., 2003), the collected data were synthesized narratively, as it is the simplest and most popular (Tranfield et al., 2003). The themes are identified and organized as Clarke \& Braun (2013) recommended.

\section{RESULTS AND DISCUSSIONS}

This section begins with an analysis of the reviewed articles' fit. The section then describes the conceptualizations of brand and product management as proposed by previous studies and finds empirical support and theoretical arguments for the research question of this review.

\section{Analysis of reviewed articles fit}

Articles related to the issues were found to be published in 72 reputed peerreviewed journals (See Table 3). Numerous journals are considering the concept. The dominant outlet of research has been the Journal of business research, Procedia-Social and behavioral sciences, and the European Journal of Marketing. Also, the variety of journals that have published articles demonstrates the widespread interest and applicability of the concept. Articles were classified based on their year of publication from 2010 to 2021 to identify the longitudinal pattern of academic research. As a result, $41 \%, 40 \%$, and $19 \%$ of the literature were published between 2010 and 2013, 20142017, and 2018-2021, implying slightly decreasing trends in the concepts.

Articles were classified based on the number of authors publishing to understand the composition of the ideas used to conduct the studies. Surprisingly, the majority $(82 \%)$ of reviewed papers were multiple-authored pieces, with the mean being 2.37 authors, while $18 \%$ were sole-authored. This portrayed that the review was conducted using ideas from different authors. Methodologically, most papers reviewed (84\%) were drawn on some form of empirical evidence. $52 \%$ of articles considered for review utilized the quantitative approach, $21 \%$, and $27 \%$ qualitative and mixed approaches, respectively. This implies a slightly higher proportional use of quantitative data, which is surprising that there wasn't a greater use of qualitative data given the nature of the field.

Additionally, about $98 \%$ of the articles made significant use of cross-sectional analysis, which tended to be based on data collected simultaneously. In comparison, only a small percentage of the papers $(2 \%)$ were based on longitudinal studies. This may affect the conclusion made by the reviewed studies as the nature of the concepts needs time to identify problems that come across. Yet $42 \%$ of articles were from Asian countries (focusing on China and India), 31\% from Europe and Africa, 18\% from the US context, and $9 \%$ from unknown countries. Further, $78 \%$ and $22 \%$ of the articles are private and public organizations. As well as $82 \%$ and $18 \%$ of it based on large and SMEs respectively. 
Table 3. List of journals with number of published papers

\begin{tabular}{lc}
\hline Journal Name & Number of Papers \\
\hline Journal of business research & 6 \\
Procedia-Social and behavioral sciences & 5 \\
European Journal of Marketing & 4 \\
Journal of the academy of marketing science & 4 \\
Journal of Strategic Marketing & 3 \\
Food quality and preference & 2 \\
Journal of Marketing & 2 \\
Industrial Marketing Management & 2 \\
International Journal of Bank Marketing & 2 \\
Journal of Retailing and Consumer Services & 2 \\
Management Science & 2 \\
Psychology \& Marketing & 2 \\
Work & 2 \\
\hline
\end{tabular}

Journals published one are: Administrative Sciences, Advances in Business Research International Journal, African Journal of Economic and Management Studies, Annual review of anthropology, A holistic and practical approach to uncertainty reduction; Applied ergonomics, Asia Pacific Management Review, Athens journal of business and economic, BMC medical research methodology, British journal of management, Culinary science and hospitality research, CIRP Journal of Manufacturing Science and Technology, Design Studies, Decision Sciences, Economic Review: Journal of Economics and Business, EurOMA, Cambridge, European Management Journal, European Journal of Business and Management, European Scientific Journal, Expert systems with applications, Fashion and Textiles, In Journal of Physics: Conference Series, In Managing Innovation: What Do We Know About Innovation Success Factors? International Conference on Innovation Management and Technology Research , International Journal of Business and Society, International Journal of Economics and Management Sciences, International Journal of Hospitality Management, International Journal of New Technology and Research, International Journal of Production Economic, International Journal of Quality \& Reliability Management, International Journal of Research in Marketing, Industrial Management \& Data Systems, IOSR Journal of Business and Management, IUP Journal of Brand Management, Journal of Asia Business Studies, Journal of Basic and Applied Scientific Research, Journal of Brand management, Journal of CENTRUM Cathedra: The Business and Economics Research Journal, Journal of Consumer Marketing, Journal of Customer Behavior, Journal of Economics, Business and Management, Journal of Global Marketing, Journal of Global Strategic Management, Journal of Industrial Engineering and Management, Journal of International Studies, Journal of Islamic Studies and Culture , International Journal of Innovation Science, Journal of Marketing Research, Journal of Northeast Agricultural University, Journal of Place Management and Development, Journal of Product \& Brand Management, Journal of Product Innovation Management, Journal of Research in Marketing and Entrepreneurship, Journal of Retailing , Journal of software: Evolution and Process, Journal of Sociological Research, Journal of wine research, Jurnal Komunikasi, Management Decision, Malaysian Journal of Communication, Marketing Intelligence \& Planning, Marketing Theory, Mediterranean Journal of Social Sciences, Oradea Journal of Business and Economics, Project, Procedia CIRP, Springer, Berlin, Heidelberg, Swot, Sumedha Journal of Management, Sustainability, Transportation Research: Logistics and Transportation Review, Technology in Society, Technovation, The Journal of Asian Finance, Economics, and Business, The psychologist

\section{The concept of branding and brand management}

The majority of the reviewed literature (e.g., Ahmad et al. 2016; Janoskova \& Kliestikova 2018; Dessart et al. 2019; Mao et al. 2020) related the term branding with the 1960 classic definition proffered by the American Marketing Association, which linked brands to the identity of a product as well as its differentiation from its competitors by the use of a clearly distinguishable name, term, visual signs, and symbols (see Table 4). These attributes represent the promise made by a business to consistently provide its customers with a certain defined set of product features, benefits, and services (Ahmed et al., 2014). Therefore, the fundamental objective of branding is creating and developing a deep group of positive points that will enable customers to hold favorable brand associations in their minds. 
Managing the brands of products or services provided by the organizations is one of the techniques for developing a good relationship with target markets (M'zungu, et al., 2010). Branding is considered as a communication function in marketing, which incorporates investigation and planning for how the brand is positioned in the market, identifying who the brand is targeted at, and maintaining the expected status of the brand in the business environment (Takalkar, 2014). Janoskova \& Kliestikova (2018) concluded that brand management is a continuous process that integrates all activities, procedures, and tools applied to increase brand value. Huang \& Tsai (2013) state that the management of a brand is a strategic and widespread activity of the entire company.

Table 4. Branding and brand management concepts

\begin{tabular}{ll}
\hline Author(s) & Descriptions \\
\hline Dessart et al. (2019) & $\begin{array}{l}\text { Brand management studies how a brand is perceived, planning how it } \\
\text { should be perceived in the business environment, and confirming that } \\
\text { it is perceived as planned and acquires the pre-stated aims. }\end{array}$ \\
\hline M'zungu et al. (2010) & $\begin{array}{l}\text { Brand management develops better ways to build and maintain a } \\
\text { continuing and good relationship with customers. }\end{array}$ \\
\hline Takalkar (2014) & $\begin{array}{l}\text { Brand management is a communication function in marketing used to } \\
\text { analyze and plan to ensure the appropriate brand positioning in the } \\
\text { market, identify target customers, and preserve the brand's current } \\
\text { status. }\end{array}$ \\
\hline Paul (2019) & $\begin{array}{l}\text { Effective brand management allows for building loyal customers and } \\
\text { improves the value of products in the business environment due to } \\
\text { positive brand associations and images or strong brand awareness. }\end{array}$ \\
\hline $\begin{array}{l}\text { Dolbec \& Chebat } \\
\text { (2013) }\end{array}$ & $\begin{array}{l}\text { Strategic brand management helps clarify and communicate the } \\
\text { brand's identity, personality, and associations. The brand } \\
\text { communicates concerning its history and to the current competitive } \\
\text { environment. }\end{array}$ \\
\hline McDonalds \& Wilson, & $\begin{array}{l}\text { The involvement in new product development, exploring alternative } \\
\text { modes of marketing communications, building customer } \\
\text { (2011) }\end{array}$ \\
$\begin{array}{l}\text { relationships, and ensuring equity between brand price and consumer } \\
\text { value enhances the brand management activities. }\end{array}$ \\
\hline Huang \& Tsai (2013) & $\begin{array}{l}\text { Brand management is a strategic and comprehensive activity rather } \\
\text { than a tactical or functional activity of the entire company. }\end{array}$ \\
\hline Janoskova \& & $\begin{array}{l}\text { Brand management is a continuous process that integrates all } \\
\text { activities, procedures, and tools applied to increase brand value. }\end{array}$ \\
\hline Kliestikova (2018)
\end{tabular}

Hence, to properly understand the developed brands of the organization and their target customers, brand management is required to maintain the firm's brand equity. Since brand equity measures customers' attachment, association, and beliefs, the consumer has about the brand (Dolbec \& Chebat 2013). Paul (2019) concluded that effective brand management enables the building of loyal customers, better brand associations, positive images of the brand, and better awareness.

Then, the importance of the brand gradually disappears; it is no longer a significant attribute of customer buying decisions because the product is no longer unique concerning competitive offers. The brand owner can not apply a high trading margin and lose its position in this situation. Thus, it is expected of a brand manager to oversee all aspects of branding to be competitive (M'zungu et al., 2010). It can be realized from the above-stated concept of brand management as it circulates around an analysis of current perceptions of customers towards a brand, proceeds to plan how to safeguard better brand images, and lasts with certifying that the brand is supposed as 
prearranged and acquires its objectives. Simply, Dessart et al. (2019), the definition of brand management is the most comprehensive one.

\section{Evolutions and development of brand/product management}

From the extensive review of the kinds of literature, Table 5 (appendix) presented the identified brand/product management approaches sequentially with the focus areas, assumption followed, and theoretical base and methodology disparity.

\section{The economic use approach}

The income-based or economic use approach is the valuation of future net earnings directly attributable to the brand to determine its value in its current use (Liu et al., 2017). This method is extremely effective as it shows the future potential of a brand that the owner currently enjoys. The value is useful compared to the open market valuation as the owner can determine the benefit foregone by pursuing the current course of action (Rahinel \& Redden, 2013). According to these premises, the primary purpose of brand management is to produce, promote, and distribute goods that are attractive to consumers.

The economic approach explores how changes in one or more marketing mix factors (Sheth \& Koschmann, 2019). These premises make the utility attributes the brand has to offer judged against its price relative to competitors, level of awareness and recognition, and last but not least, the accessibility of the brand essential for whether or not a brand will be successful. Hence, Brand managers are assumed to control consumers' brand choice behavior by ensuring an optimum mix between the four main marketing mix elements (Deleersnyder \& Koll 2012). Hence, the marketing mix is a key instrument for understanding and facilitating transactions between the company and the market.

The logic is that a brand will succeed only if the manufacturer of that brand is able to produce a product that delivers high utility benefits, then sells it at the right price, in the right places, and promotes it to such an extent and in such a way that spurs consumer awareness (Ataman et al., 2010). Most research literature characterizing the economic approach era was directed at exploring and understanding how different marketing mix factors affect the consumers' brand choice. Generally, this approach sees the brand as part of the traditional marketing mix. The literature examined within this approach (like Mehta \& Ma, 2012; Stahl et al., 2012) revealed that consumers are assumed to make rational brand choice decisions, focusing on products that maximize usefulness.

The approach focuses only on product-level activities. Examining literature during the economic approach era revealed that the most predominant methodologies adopted were quantitative and concentrated on understanding the impact of one or more elements of the marketing mix on consumer brand choice behavior. Predominantly derived from scanner panel data, the data are usually factual and statistically measurable. Thus it is generally accepted that an economic approach is still a suitable tool for planning and execution in brand management. But this alone is not enough to create or build a very successful brand in modern times. Hence, the need for newer approaches that consider how and why modern consumers consume brands.

\section{The identity approach}

The study of Hatch \& Schultz (1997) titled "Relationship between organizational culture, identity and image" was the most influential literature that contributed to the identity approach. Few of the most recent studies by Balmer (2012); Chattopadhyay (2016); Fajardo et al. (2016); Wheeler (2016); Balmer \& Chen (2017); Otubanjo \& Adegbile (2019) consider the brand as having links to corporate identity with some 
modifications of Hatch \& Schultz, (1997) study. The general thinking of the identical approach as collected from literature is built on the assumption that a strong and coherent brand identity is necessary to create brand value. Thus, to create one coherent identity that meets all stakeholders' expectations, the brand must answer the vital question 'who are we?' as an organization.

Additionally, reviewed literature stated identity approach as the second oldest for brand management with some changes. A shift from focusing on the product-level activities to corporate-level branding activities is noticed in this approach, as managers focus more on how organizational behavior affects identity, image, and reputation instead of focusing solely on the visual attributes of the product alone. In this approach, the consumer's initial assumption and perception as a passive recipient of identity messages also changed as managers discovered that identity could not be effectively linearly communicated to the consumers but by interactive negotiation among all stakeholders involved.

Further, the theoretical foundations behind the core concept of brand identity are corporate identity. Organizational identity theories pertain to the internal aspects of the branding process, while image and reputation are two supporting thematic theories that cater to the external aspects. As gathered from literature, each of these four supporting themes is aligned together for a coherent brand identity to be created and believed to be important in the construction of brand identity.

Furthermore, a review of existing literature revealed that literature on the identity approach usually adopted a mix of research methodologies that depended on which of the four supporting themes was under examination or study. Studies that examined corporate identity data usually applied a heuristic methodology; those which studied organizational identity often applied methodologies with firm foundations in anthropology and cultural studies. A mixture of qualitative and quantitative methodologies drawn from cognitive and social psychology was applied for image and reputation due to their suitability. Thus, the approaches nevertheless are still relevant today. Still, the need for subsequent approaches is documented to have arisen out of a need to better understand consumer behavior both in brand choice and purchase quantity.

\section{The consumer-based approach}

The study of Keller (1993) titled Conceptualizing, Measuring and Managing Customer-based Brand Equity was founded on an entirely new approach to brand management. Based on this study, numerous pieces of literature are found. A few of those studies are Sweldens et al. (2010); Meyvis et al. (2012); Datta et al.(2017); Chan et al.(2018); Milberg et al. (2019) and Wu et al. (2019) those considered the brand as linked to consumer associations. The reviewed literature indicated that in this approach, the brand is assumed first to be a cognitive construal in the minds of consumers and secondly that consumers hold strong, unique, and favorable associations for a strong brand.

It also assumes that although the brand resides in the consumer's mind, the marketer can still control brand value creation linearly. Also, the cognitive consumer perspective, the information-processing theory of consumer choice, and the theory of customer-based equity are the three distinct theories that form the building blocks of this approach. The three major research methods were common in most literature based on this approach. From the methodological aspects, the Input-output methodologies help understand how customer decisions change when stimuli are changes; process 
tracing methods help analyze the process of brand choice among consumers and methods for measuring consumer-based brand equity.

\section{The personality approach}

The other new approach to brand management had been born with the study of Aaker (1997) when he published his research study into brand personality. His study showed that consumers tended to view and attribute human-like qualities to brands. The study was conducted by Das et al. (2012); Ivens \& Valta (2012); Choi \& Winterich (2013); Ahmad \& Thyagaraj (2014); Klipfel et al. (2014); Orth \& Rose (2017) and Luffarelli et al. (2019) are among the recent few of the studies based on the work of Aaker (1997) and considered the brand as a resembling a human character.

The reviewed literature indicated that the human-brand perspective and the symbol-consuming consumer focused on this approach. The approach assumed that personality traits are important drivers of the emotional bonding between a brand and its consumer. Personality, consumer self, and brand-self congruence are the guiding theoretical frameworks in studying brand personalities. Examining existing literature revealed scaling techniques and other relevant mixes of quantitative and qualitative research methods to uncover brand personality in the data collection and analysis processes.

\section{The relational approach}

The reviewed literature indicated that this approach was popular when Consumers and their brands: developing relationship theory in consumer research by Susan Fournier was first published in the Journal of Consumer Research (March 1998). Since then, a lot of studies have been conducted few of them that are used for this review purpose are the following: Donovan et al. (2012); Miller et al. (2012); Sela et al. (2012); Travail et al. (2016); Wang \& John. (2019). This literature considered the brand as a viable relationship partner and built on the human brand metaphor of the identity approach.

The examined studies concluded that this approach indicated a significant shift from the positivistic paradigm to a more interpretive stance. As earlier approaches assumed, the consumer is an existential being, not a passive one. It also assumed that brands were dyadic, capable of having a relationship with the consumer. A literature review reveals that theories of animism, human relationships, and theories of brand relationships shaped literature under this approach. Further, the most commonly observed research methodologies adopted were in-depth interviews and life story methods of data collection and analyses.

\section{The community approach}

The study conducted by Muniz \& O'Guinn (2001) on the title of Brand community influenced and popularized this approach. The works of Kahr et al. (2016); Kupfer et al. (2018); Shen \& Sengupta (2018); Herhausen et al. (2019); Ordenes et al. (2019) are among the few studies that conducted on this approach and considered for this review. Those studies consider the brand a focal point of social interaction.

The reviewed studies indicated as this approach is based on the observation that consumers form communities around brands, thus making the brand a focal point of social interaction among enthusiastic users of a particular brand. Further, the approach is based on two assumptions: a triadic brand relationship and the brand's perception as a social brand. The latter is a new concept added to brand management by this approach. The community theory, theories of subcultures and consumption, and the brand community theory are all theoretical frameworks that shaped literature based on this 
approach. A literature review also showed that Ethnographic and Netographic methods are some of the most prominent research methods used in studies in this approach.

\section{The cultural approach}

The reviewed literature reveals that just like the community approach, the cultural approach emanated somewhere around the millennium but was made more prominent and popular with the work of Holt (2002) titled: 'Why do brands cause trouble? A dialectic theory of consumer culture and branding'. Thus, it can be concluded that this study introduced the cultural brand perspective to brand management literature. A few of the studies that based on the work of Holt (2002) are Holt \& Cameron (2010); Luedicke et al. (2010); Torelli et al. (2012); Jutterström \& Norberg (2013); Andersen et al. (2019) which considered for this review purpose as well as the assumptions of brand to be a cultural object giving rise to both a very strong anti-branding discourse as well as a now prominent theory on how to build an iconic brand.

Further, theories that form the building blocks of this approach include the theory of cultural branding, the No Logo movement and its resistance to branding, and the citizen-assist brand prospect. The authors note that this approach borrows a lot from the scientific tradition of cultural studies and uses a wide variety of qualitative methods, the most prominent of which is the application of macro-level analytical methods to microlevel data.

\section{The sensory approach}

Like other approaches, the Sensory approach was made more prominent and popular with Dauce \& Rieunier (2002) titled: Point-of-sale sensory marketing. Few of the study that considered for review those base on this study are Bouzaabia (2014); Hulten (2015); Fajardo et al. (2016); Jiang et al. (2016); Rahinel \& Nelson (2016); Krishna et al. (2017); Rodrigues (2018); Huang et al. (2019). Those kinds of literature considered the product brand as experienced through our senses.

The reviewed literature indicated that the previous approaches focused only on two senses (hearing and sight) to distinguish their products or services from the competitors. However, using only audiovisual impetus is not sufficient for distinguishing a brand to the customer in the contemporary condition. Therefore, branding has become very popular in recent times due to the contribution of five senses - taste, touch, hearing, sight, and smell. Sensory branding allows the company to use new communication channels. The main aim of sensory branding is to simultaneously combine all the five senses to build five-dimensional know-how for the consumers. To identify the brand, consumers must use more than one sense to recognize a brand.

The importance of the five senses in the transmission of perceptions and generation of experiences depends on the nature of the product or service and the stage of buying behavior in question. Research has shown that the involvement of multiple senses can have a multiplier effect on perceptions when the senses in question communicate synergistic messages. In other words, each sensory stimulus reinforces the messages conveyed by all the others, giving rise to stronger, more consistent, and more holistic perceptions. Multisensory perceptions, therefore, facilitate faster product recognition and attribution in response to stimuli, higher processing speeds, and better assessment of the message. The sensory approach defines itself clearly in opposition to the information-processing consumer perspective.

The exchange is perceived as linear and co-created but is primarily individual in both cases. The sensory approach acknowledges the interplay between sensory and mental systems in creating brand responses. The core theme of the sensory approach is that brands offer consumers and customers sensory experiences, which lead to stronger 
brand affiliation. The product is merely an artifact; the brand is a collection of symbolic meanings around which it is possible to build the sensory experiences individual consumers strive for. Hence the product itself is no longer the ultimate goal. The brand's purchase and consumption are also strongly driven by the self-fulfillment that the sensory experience of the brand provides. Further, the most commonly observed research methodologies adopted were in-depth interviews and life story methods of data collection and analyses.

\section{Practical implications}

In summary, the article progresses the idea that successful branding is about smart, creative brands and well-planned and executed brand management. Strong brands need to be well articulated, communicated, developed internally, and delivered consistently. Intangible resources such as brands not only need to be recognized but also safeguarded through well-designed brand management methods, and not simply by legal means.

Over time, the historical reality of brand and product management research trends tells us that no form of management is- or should be permanent. The continued presence of name brands testifies to the overall effectiveness of brand management over long periods through all three of the major historical forms that have been elucidated here. The historical reality that three distinct forms of brand management have existed over the past century should tell us that no form of management is- or should be permanent. Though the brand manager system as we know it could come to an end, brand management itself almost certainly will continue to thrive.

\section{Managerial implications}

As the current research shows brand and product management's importance, managers need to formulate effective and efficient marketing strategies to build, manage, and maintain a connection between consumers and brands and products in a highly competitive, globalized, and dynamic business environment. The review benefits the marketing practitioners the most, especially those involved in planning strategies in brand and product management. Effectively, managing is fundamental to securing a competitive edge. Hence, the findings expose valuable insights for marketers to identify the cause of brand and product management that affect brands and products values that affect the next purchase.

The identified approaches of brand and product management make the managers ensure that consumers and stakeholders alike experience a very strong and coherent identity in all of their contacts with it; create and manage personality by using both direct and indirect sources; aware that brands/products had to act as true friends if they were to create a bond in the minds of consumers; being facilitator and view that the management of an iconic brand requires the ability to think and act like a cultural activist and also a careful consideration of corporate social responsibility.

\section{Strength, limitations, and further research}

The strength of this review is that it is the first time study to conduct a comprehensive, systematic literature search to identify frameworks and empirical studies describing the current focus of marketing activity of organizations. Hence, this review provides a strong basis for future marketing researchers. Further, this review aimed to clarify, associate, and identify brand and product management evolutions by linking the existing theoretical and empirical paths. The present review cannot be ruled out that some concepts were missed because the reviewed literature searched for the 
terms in their title or abstract, which may exclude studies presenting those terms in their abstract and title sections.

The potential consequences concerning the combined use of these marketing aspects are theoretical and need to be evaluated through empirical studies. Further research, however, is required in this area to identify additional variables that could add to the explanatory power of the concept. As this study takes a qualitative perspective with a research journal analysis, additional empirical research is needed, such as quantitative data, to identify branding and product management strategies comprehensively. The lack of conceptual clarity regarding brand and product management leads to future scholars' clear-cut solutions.

\section{CONCLUSIONS}

In reviewing the brand and product research trends over time, it was clear to see eight different brand and product management approaches identified since the concept's inception to 2021. These approaches include the economic approach, the identity approach, the consumer-based approach, the personality approach, the relational approach, the community approach, the cultural approach, and the sensory approach, respectively, from oldest to latest approaches. It was noted that all of these approaches are different in their focus areas. The first period emphasized product-related activities, followed by corporate-related activities, consumer associations activities, human-like character activities, viable relationship partnerships, social interaction activities, cultural fabric activities, and Multisensory insights. As well as, all of these approaches are different in terms of assumptions followed to achieve the objective and the based theoretical themes.

It was also noted that a major paradigm shift occurred at the birth of the relational approach in 1998, and this shift brought with it an important shift away from a more quantitative research methods era to more qualitative methods and also the realization and acceptance by product managers that the customers own the brand and product as well as the involvement of multiple senses to build five-dimensional know-how for the consumers. Accordingly, effective use of brand equity and brand management offers marketers one route for enhancing the initial selection probability, developing loyalty, retaining customers, and building or enhancing relationships.

\section{REFERENCES}

Ahmad, Z., Jun, M., Khan, I., Abdullah, M., \& Ghauri, T. A. (2016). Examining Mediating Role of Customer Loyalty for Influence of Brand Related Attributes on Customer Repurchase Intention. Journal of Northeast Agricultural University (English Edition), 23(2), 89-96.

Ahmad, A. \& Thyagaraj, K. S. (2014). Brand personality and brand equity research: Past developments and future directions. IUP Journal of Brand Management, 11 (3)

Ahmed, Z., Rizwan, M., Ahmad, M., \& Haq, M. (2014). Effect of brand trust and customer satisfaction on brand loyalty in Bahawalpur. Journal of Sociological Research, 5(1), 306-326.

Alano, A.B., Figueiredo, L. F., Merino, E. A. D., \& Merino, G. S. A. D. (2015). Design and ergonomics: bases for identifying demands in a creative community. Project, $6(1), 39-60$. 
Aksoy, H. (2017). How do innovation culture, marketing innovation and product innovation affect the market performance of small and medium-sized enterprises (SMEs). Technology in Society, 51(4), 133-141.

Andersen, L. P., Kjeldgaard, D., Östberg, J. \& Lindberg, F. (2019). Nordic branding: An Odyssey into the Nordic myth market, in J. Östberg \& S. Askegaard Nordic Consumer Culture: Exploring the State, Market and the Consumers, London: Palgrave Macmillan

Ataman, M. B.,Van Heerde, H. J. \& Mela, C. F. (2010). The long-term effect of marketing strategy on brand sales. Journal of Marketing Research, 47(5), 866882

Aurich, J. C., Mannweiler, C., \& Schweitzer, E. (2010). How to design and offer services successfully. CIRP Journal of Manufacturing Science and Technology, 2(3), 136-143.

Balmer, J. M. T. (2012). Strategic corporate brand alignment: Perspectives from identity based views of corporate brands. European Journal of Marketing, 46 (7/8), 10641092

Balmer, J. M. T. \& Chen, W. (2017). Corporate heritage brands, augmented role identity and customer satisfaction. European Journal of Marketing, 51 (9/10): $1510-1521$

Bhuiyan, N. (2011). A framework for successful new product development. Journal of Industrial Engineering and Management (JIEM), 4(4), 746-770.

Bouzaabia, R. (2014). The effect of ambient scents on consumer responses: Consumer type and his accompaniment state as moderating variables. International Journal of Marketing Studies, 6 (1)

Brodie, R. J., Benson-Rea, M., \& Medlin, C. J. (2017). Branding as a dynamic capability: Strategic advantage from integrating meanings with identification. Marketing Theory, 17(2), 183-199.

Chan, C. W., Green, L. V., Lekwijit, S., Lu, L., \& Escobar, G. (2019). Assessing the impact of service level when customer needs are uncertain: An empirical investigation of hospital step-down units. Management Science, 65(2), 751-775.

Chan, H., Boksem, M. \& Smidts, A. (2018) . Neural profiling of brands: Mapping brand image in con- sumers' brains with visual templates. Journal of Marketing Research, 55(4), 600-615

Chattopadhyay, A. (2016). Does your company have the right logo? How and why circular and angular logo shapes influence brand attribute judgments. Journal of Consumer Research, 42 (5), 709-726

Chen, H. B., Yeh, S. S., \& Huan, T. C. (2014). Nostalgic emotion, experiential value, brand image, and consumption intentions of customers of nostalgic-themed restaurants. Journal of Business Research, 67(3), 354-360.

Chen, K. H., Wang, C. H., Huang, S. Z., \& Shen, G. C. (2016). Service innovation and new product performance: The influence of market-linking capabilities and market turbulence. International Journal of Production Economics, 172, 54-64.

Chen, X., Lam, L. W., \& Zou, H. (2011). Antecedents and Performance Consequences of Integrated Brand Management in China: An Exploratory Study. Journal of Global Marketing, 24(2), 167-180.

Choi, W., \& Lee, Y. (2019). Effects of fashion vlogger attributes on product attitude and content sharing. Fashion and Textiles, 6(1), 1-18. 
Choi, W. J. \& Winterich, K. P. (2013) . Can brands move in from the outside? How moral identity enhances out-group brand attitudes. Journal of Marketing, 77 (2), 96-111

Clarke, V., \& Braun, V. (2013). Teaching thematic analysis: Overcoming challenges and developing strategies for effective learning. The psychologist, 26(2), 120-123

Das, G., Guin, K. \& Datta, B. (2012). Developing brand personality scales:A literature review. The IUP Journal of Brand Management, 9 (2), 44-63

Datta, H., Ailiwada, K. L. \& van Heerde, H. J. (2017) . How well does consumer-based brand equity align with sales-based brand equity and marketing-mix response?' Journal of Marketing, 81 (May), 1-20

Deleersnyder, B. \& Koll, O. (2012). Destination discount: A sensible road for national brands?' European Journal of Marketing, 46 (9), 1150-1170

Dessart, L., Aldás-Manzano, J., \& Veloutsou, C. (2019). Unveiling heterogeneous engagement-based loyalty in brand communities. European Journal of Marketing.

Dirisu, J. I., Iyiola, O., \& Ibidunni, O. S. (2013). Product differentiation: A tool of competitive advantage and optimal organizational performance (A study of Unilever Nigeria PLC). European Scientific Journal, 9(34), 258-281

Dolbec, P. Y., \& Chebat, J. C. (2013). The impact of a flagship vs. a brand store on brand attitude, brand attachment and brand equity. Journal of Retailing, 89(4), 460-466.

Donovan, L. A. N., Priester, J. R., MacInnis, D. J. and Park, C. W. (2012). Brand forgiveness: How close brand relationships influence brand forgiveness. in S. Fournier, M. Breazeale and M. Fetscherin (eds) Consumer-Brand Relationships, Abingdon: Routledge

Fajardo,T. M., Zhang, J. \& Tsiros, M. (2016). The contingent nature of the symbolic associations of visual design elements: The case of brand logo frames. Journal of Consumer Research, 43 (4), 549-566

Gupta, S., Dangayach, G. S., \& Singh, A. K. (2015). Key determinants of sustainable product design and manufacturing. Procedia CIRP, 26, 99-102.

Herhausen, D., Ludwig, S., Grewal, D.,Wulf, J. \& Schoegel, M. (2019). Detecting, preventing, and miti- gating online firestorms in brand communities. Journal of Marketing, 83 (3), 1-21

Holt, D. B. \& Cameron, D. (2010). Cultural Strategy: Using Innovative Ideologies to Build Breakthrough Brands, Oxford: Oxford University Press

Huang, X., Dong, P. \& Zhang, M. (2019). Crush on you: Romantic crushes increase consumers' preferences for strong sensory stimuli. Journal of Consumer Research, 46 (1), 53-68

Huang, Y. T., \& Tsai, Y. T. (2013). Antecedents and consequences of brand-oriented companies. European journal of marketing. 47(11/12), 2020-2041

Hult, G. T. M., Sharma, P. N., Morgeson III, F. V., \& Zhang, Y. (2019). Antecedents and consequences of customer satisfaction: do they differ across online and offline purchases?. Journal of Retailing, 95(1), 10-23.

Hulten, B. (2015). Sensory Marketing, Empirical and Theoretical Grounds, Abingdon: Routledge

Ivens, B. \& Valta, K. S. (2012) . Customer brand personality perception: A taxonomic analysis. Journal of Marketing Management, 28 (9-10), 1062-1093

Janoskova, K., \& Kliestikova, J. (2018). Analysis of the impact of selected determinants on brand value. Journal of International Studies, 11(1), 152-162. 
Jiang,Y., Gorn, G. J., Galli, M. \& Chattopadhyay, A. (2016). Does your company have the right logo? How and why circular and angular logo shapes influence brand attribute judgments. Journal of Consumer Research, 42(5), 709-726

Jutterström, M. \& Norberg, P. (2013). CSR as a management idea. in M. Jutterström \& P. Norberg (eds) CSR as a Management Idea, Cheltenham: Edward Elgar Publishing

Kahr, A., Nyffenegger, B., Krohmer, H. \& Hoyer,W. D. (2016). When hostile consumers wreak havoc on your brand: The phenomenon of consumer brand sabotage. Journal of Marketing, 80 (May): 25-41

Kanagal, N. B. (2015). Innovation and product innovation in marketing strategy. Journal of Management and Marketing Research, 18, 1-25

Krishna, A., Cian, L. \& Aydinoglu, Z. (2017). Sensory aspects of package design. Journal of Retailing, 93 (1), 43-54

Klipfel, J. A., Barclay, A. C., \& Bockorny, K. M. (2014). Self-congruity: A determinant of brand personality. Journal of Marketing Development \& Competitiveness, 8 (3), 130-143

Kupfer, A., Pähler vor der Holte, N., Kübler, R. V. \& Hennig-Thurau,T. (2018). The role of the partner brand's social media power in brand alliances. Journal of Marketing, 82 (May): 25-44

Li, G., Zhang, R., \& Wang, C. (2015). The role of product originality, usefulness and motivated consumer innovativeness in new product adoption intentions. Journal of Product Innovation Management, 32(2), 214-223.

Liu,Y., Li, K. J., Chen, H. \& Balachander, S. (2017). The effects of products' aesthetic design on demand and marketing-mix effectiveness: The role of segment proto typicality and brand consistency. Journal of Marketing, 81 (1), 83-102

Luedicke, M., Thompson, C. \& Giesler, M. (2010) 'Consumer identity work as moral protagonism: How myth and ideology animate a brand-mediated moral conflict,' Journal of Consumer Research, 36 (6), 1016-1032

Luffarelli, J., Stamatogiannakis, A. \& Yang, H. (2019). The visual asymmetry effect: An interplay of logo design and brand personality on brand equity. Journal of Marketing Research, 56 (1), 89-103

Mao, Y., Lai, Y., Luo, Y., Liu, S., Du, Y., Zhou, J., \& Bonaiuto, M. (2020). Apple or Huawei: understanding flow, brand image, brand identity, brand personality and purchase intention of smartphone. Sustainability, 12(8), 3391.

McDonald, M. \& Wilson, H. (2011). Marketing plans: How to prepare them, how to Use Them. Hoboken, N.J.: Wiley \& Sons, p. 580.

Mehta, N. \& Ma,Y. (2012). A multicategory model of consumers' purchase incidence, quantity, and brand choice decisions: Methodological issues and implications on promotional decisions. Journal of Marketing Research, 49 (4), 435-451

Meyvis,T., Goldsmith, K. \& Dhar, R. (2012). The importance of the context in brand extension: How pictures and comparisons shift consumers' focus from fit to quality. Journal of Marketing Research, XLIX (April), 206-217

Milberg, S. M., Sinn, F. \& Goodstein, R. C. (2010). Consumer reactions to brand extensions in a com- petitive context: Does fit still matter?' Journal of Consumer Research, 37, 543-553

Miller, F. M., Fournier, S. \& Allen, C. T. (2012). Exploring relationship analogues in the brand space. in S. Fournier, M. Breazeale \& M. Fetscherin (eds) ConsumerBrand Relationships, Abingdon: Routledge 
Munn, Z., Peters, M.D., Stern, C., Tufanaru, C., McArthur, A. \& Aromataris, E., (2018). Systematic review or scoping review? Guidance for authors when choosing between a systematic or scoping review approach. BMC medical research methodology, 18(1), 1-7.

M'zungu, S. D., Merrilees, B., \& Miller, D. (2010). Brand management to protect brand equity: A conceptual model. Journal of Brand management, 17(8), 605-617.

Ordenes, F. V., Grewal, D., Ludwig, S., de Ruyter, K. Mahr, D. \& Wetzels, M. (2019). Cutting through Content Clutter: How Speech and Image Acts Drive Consumer Sharing of Social Media Brand Mes- sages. Journal of Consumer Research, 45, 988-1012

Orth, U. R. \& Rose, G. M. (2017). Consumers' brand identity complexity: Conceptualization and predictive ability. European Journal of Marketing, 51(2), 304-323

Otubanjo, O. \& Adegbile, O. E. (2019) The corporate heritage brand development process: A new institutional theory approach, IUP Journal of Brand Management, $16(1), 7-33$

Paul, J. (2019). Masstige model and measure for brand management. European Management Journal, 37(3), 299-312.

Pinar, M., Girard, T., Trapp, P., \& Eser, Z. (2016). Services branding triangle: Examining the triadic service brand promises for creating a strong brand in banking industry. International Journal of Bank Marketing.

Rahinel, R. \& Nelson, N. M. (2016). When brand logos describe the environment: Design instability and the utility of safety-oriented products. Journal of Consumer Research, 43(3), 478-496

Rahinel, R. \& Redden, J. P. (2013). Brands as product coordinators: Matching brands make joint consumption experiences more enjoyable. Journal of Consumer Research, 39 (6), 1290-1299

Rodrigues, C. (2018) Multisensory Brand Experiences and Brand Love, in: Driving Customer Appeal Through the Use of Emotional Branding, (Eds. Garg, R., Chhikara, R., Panda, T.K. \& Kataria, A.), Hershey (USA): IGI Global

Sela, A., Wheeler, S. C. \& Sarial-Abi, G. (2012). We are not the same as you and I: Causal effects of minor language variations on consumers' attitudes towards brands. Journal of Consumer Research, 39 (October), 644-661

Shaari, H., \& Hussin, Z. (2012). Relationship between brand knowledge and brand rewards, and employees' brand citizenship behavior: the mediating roles of brand commitment. International Journal of Business and Society, 13(3), 335-354.

Shen, H. \& Sengupta, J. (2018). Word of mouth versus word of mouse: Speaking about a brand connects you to it more than writing does. Journal of Consumer Research, 45, 595-614

Sheth, J. \& Koschmann, A. (2019). Do brands compete or coexist? How persistence of brand loyalty segments the market. European Journal of Marketing, 53 (1), 2-19

Stahl, F., Heitmann, M., Lehmann, D. R. \& Neslin, S. A. (2012). The impact of brand equity on customer acquisition, retention, and profit margin. Journal of Marketing, 76 (4), 44-63

Sweldens, S., van Osselaer, S. M. J. \& Janiszewski, C. (2010). Evaluative conditioning procedures and the resilience of conditioned brand attitudes. Journal of Consumer Research, 37 (October), 473-489 
Tajeddini, K., \& Ratten, V. (2020). The moderating effect of brand orientation on interfirm market orientation and performance. Journal of Strategic Marketing, 28(3), 194-224.

Takalkar, S. D. (2014). Brand Strategy Management. Sumedha Journal of Management, $3(3), 129$.

Tijssen, I. O., Zandstra, E. H., den Boer, A., \& Jager, G. (2019). Taste matters most: Effects of package design on the dynamics of implicit and explicit product evaluations over repeated in-home consumption. Food Quality and Preference, 72, 126-135.

Torelli, C. J., Monga, A. B. \& Kaikati, A. M. (2012). Doing poorly by doing good: Corporate social responsibility and brand concepts. Journal of Consumer Research, 38 (February): 948-963

Tranfield, D., Denyer, D., \& Smart, P. (2003). Towards a methodology for developing evidence-informed management knowledge by means of systematic review. British Journal of Management, 14(3), 207-222

Travail, C., Austin, M., Schlack, J. W. \& Lerman, K. (2016). The brands that make customers feel respected. Harvard Business Review

Wang, G., \& Miao, C. F. (2015). Effects of sales force market orientation on creativity, innovation implementation, and sales performance. Journal of business research, 68(11), 2374-2382.

Wang,Y. \& John, D. R. (2019). Up, up, and away: Upgrading as a response to dissimilar brand users. Journal of Marketing Research, 56 (1), 142-157

Wheeler, A. (2016) Designing Brand Identity: An Essential Guide for the Whole Branding Team, Hoboken, NJ: Wiley

Wu, F., Sun, Q., Grewal, R., \& Li, S. (2019). Brand name types and consumer demand: evidence from China's automobile market. Journal of Marketing Research, 56 (1), 158-175

Younus, S., Rasheed, F., \& Zia, A. (2015). Identifying the factors affecting customer purchase intention. Global Journal of Management and Business Research. 15(2) 


\section{APPENDIX}

Table 5. Approaches of brand/product management

\begin{tabular}{|c|c|c|c|c|c|}
\hline Approaches & Focus & Assumptions & Methodology & $\begin{array}{l}\text { Theoretical } \\
\text { themes }\end{array}$ & Authors \\
\hline $\begin{array}{l}\text { Economic } \\
\text { approach }\end{array}$ & $\begin{array}{l}\text { Product level } \\
\text { activities }\end{array}$ & $\begin{array}{l}\text { Market forces } \\
\text { are responsible } \\
\text { for allocating } \\
\text { and } \\
\text { distributing } \\
\text { scarce } \\
\text { resources } \\
\text { through the } \\
\text { principle of the } \\
\text { 'invisible } \\
\text { hand' }\end{array}$ & $\begin{array}{l}\text { quantitative in } \\
\text { nature }\end{array}$ & $\begin{array}{l}\text { Marketing mix } \\
\text { concept and the } \\
\text { transaction cost } \\
\text { theory }\end{array}$ & $\begin{array}{l}\text { Ataman, et al. } \\
\text { 2010; } \\
\text { Deleersnyder,. } \\
\text { \& Koll, 2012; } \\
\text { Mehta \& Ma } \\
\text { 2012; Stahl et } \\
\text { al. 2012;Liu et } \\
\text { al. 2017; } \\
\text { Rahinel \& } \\
\text { Redden 2013; } \\
\text { Sheth \& } \\
\text { Koschmann } \\
2019\end{array}$ \\
\hline $\begin{array}{l}\text { Identity } \\
\text { Approach }\end{array}$ & $\begin{array}{l}\text { Corporate } \\
\text { level activities }\end{array}$ & $\begin{array}{l}\text { To create } \\
\text { brand value, a } \\
\text { strong and } \\
\text { coherent brand } \\
\text { identity is } \\
\text { absolutely } \\
\text { necessary. }\end{array}$ & $\begin{array}{l}\text { the mixture of } \\
\text { qualitative and } \\
\text { quantitative }\end{array}$ & $\begin{array}{l}\text { Corporate } \\
\text { Identity, } \\
\text { Organizational } \\
\text { identity, image } \\
\text { and reputation } \\
\text { theories }\end{array}$ & $\begin{array}{l}\text { Balmer 2012; } \\
\text { Chattopadhyay, } \\
\text { 2016; Fajardo et } \\
\text { al. 2016; } \\
\text { Wheeler 2016; } \\
\text { Balmer \& Chen } \\
\text { 2017; Otubanjo, } \\
\text { \& Adegbile } \\
2019\end{array}$ \\
\hline $\begin{array}{l}\text { Consumer- } \\
\text { based } \\
\text { Approach }\end{array}$ & $\begin{array}{l}\text { Consumer } \\
\text { associations } \\
\text { activities }\end{array}$ & $\begin{array}{l}\text { Although the } \\
\text { brand resides } \\
\text { in the } \\
\text { consumer's } \\
\text { mind, the } \\
\text { marketer is } \\
\text { still able to } \\
\text { control brand } \\
\text { value creation } \\
\text { linearly. }\end{array}$ & $\begin{array}{l}\text { Input-output, } \\
\text { Process } \\
\text { tracing, and } \\
\text { methods for } \\
\text { measuring } \\
\text { consumer- } \\
\text { based brand }\end{array}$ & $\begin{array}{l}\text { cognitive } \\
\text { consumer } \\
\text { perspective, } \\
\text { information- } \\
\text { processing } \\
\text { theory of } \\
\text { consumer } \\
\text { choice, and } \\
\text { theory of } \\
\text { customer-based } \\
\text { equity }\end{array}$ & $\begin{array}{l}\text { Sweldens et al. } \\
\text { 2010;Meyvis et } \\
\text { al. 2012; Datta, } \\
\text { et al. } \\
\text { 2017;Chan, et } \\
\text { al. 2018; } \\
\text { Milberg et al. } \\
\text { 2019; Wu et al. } \\
2019\end{array}$ \\
\hline $\begin{array}{l}\text { Personality } \\
\text { Approach }\end{array}$ & $\begin{array}{l}\text { Human-like } \\
\text { character } \\
\text { activities }\end{array}$ & $\begin{array}{l}\text { Personality } \\
\text { traits are } \\
\text { important } \\
\text { drivers of the } \\
\text { emotional } \\
\text { bonding } \\
\text { between a } \\
\text { brand and its } \\
\text { consumer. }\end{array}$ & $\begin{array}{l}\text { Mix of } \\
\text { quantitative } \\
\text { and qualitative }\end{array}$ & $\begin{array}{l}\text { personality, } \\
\text { consumer self } \\
\text { and brand-self } \\
\text { congruence } \\
\text { theories }\end{array}$ & $\begin{array}{l}\text { Das et al. 2012; } \\
\text { Ivens \& Valta, } \\
\text { 2012; Choi \& } \\
\text { Winterich 2013; } \\
\text { Ahmad \& } \\
\text { Thyagaraj 2014; } \\
\text { Klipfel et al. } \\
\text { 2014; Orth \& } \\
\text { Rose } \\
\text { 2017;Luffarelli } \\
\text { et al. } 2019\end{array}$ \\
\hline $\begin{array}{l}\text { Relational } \\
\text { Approach }\end{array}$ & $\begin{array}{l}\text { Viable } \\
\text { relationship } \\
\text { partnership }\end{array}$ & $\begin{array}{l}\text { the consumer } \\
\text { is an } \\
\text { existential } \\
\text { being, and } \\
\text { brands are } \\
\text { dyadic in }\end{array}$ & $\begin{array}{l}\text { in-depth } \\
\text { interviews and } \\
\text { life story } \\
\text { methods }\end{array}$ & $\begin{array}{l}\text { animism, } \\
\text { theories of } \\
\text { human } \\
\text { relationships } \\
\text { and theories of } \\
\text { brand }\end{array}$ & $\begin{array}{l}\text { Donovan, et al. } \\
\text { 2012; Miller et } \\
\text { al. 2012; Sela et } \\
\text { al. 2012; } \\
\text { Travail et al. } \\
\text { 2016; Wang \& }\end{array}$ \\
\hline
\end{tabular}




\begin{tabular}{|c|c|c|c|c|c|}
\hline Approaches & Focus & Assumptions & Methodology & $\begin{array}{l}\text { Theoretical } \\
\text { themes }\end{array}$ & Authors \\
\hline & & $\begin{array}{l}\text { nature capable } \\
\text { of having } \\
\text { a relationship } \\
\text { with the } \\
\text { consumer }\end{array}$ & & relationships & John 2019 \\
\hline $\begin{array}{l}\text { Community } \\
\text { Approach }\end{array}$ & $\begin{array}{l}\text { Social } \\
\text { interaction } \\
\text { activities }\end{array}$ & $\begin{array}{l}\text { Consumers } \\
\text { form } \\
\text { communities } \\
\text { around brands } \\
\text { thus making } \\
\text { the brand a } \\
\text { focal point of } \\
\text { social } \\
\text { interaction } \\
\text { among } \\
\text { enthusiastic } \\
\text { users of a } \\
\text { particular } \\
\text { brand }\end{array}$ & $\begin{array}{l}\text { Ethnographic } \\
\text { and } \\
\text { Netographic } \\
\text { methods }\end{array}$ & $\begin{array}{l}\text { community } \\
\text { theory, theories } \\
\text { of subcultures } \\
\text { and of } \\
\text { consumption } \\
\text { and the brand } \\
\text { community } \\
\text { theory }\end{array}$ & $\begin{array}{l}\text { Kahr et al. } \\
\text { 2016; Kupfer et } \\
\text { al. 2018; Shen } \\
\text { \& Sengupta } \\
\text { 2018; } \\
\text { Herhausen et } \\
\text { al. 2019; } \\
\text { Ordenes et al. } \\
2019\end{array}$ \\
\hline $\begin{array}{l}\text { Cultural } \\
\text { Approach }\end{array}$ & $\begin{array}{l}\text { Cultural fabric } \\
\text { activities }\end{array}$ & $\begin{array}{l}\text { The brand is } \\
\text { perceived as a } \\
\text { cultural } \\
\text { artefact and a } \\
\text { cultural brand } \\
\text { perspective is } \\
\text { hence } \\
\text { introduced in } \\
\text { brand } \\
\text { management }\end{array}$ & $\begin{array}{l}\text { macro-level } \\
\text { analysis is } \\
\text { applied to } \\
\text { micro-level } \\
\text { data }\end{array}$ & $\begin{array}{l}\text { No Logo } \\
\text { movement and } \\
\text { its resistance to } \\
\text { branding and } \\
\text { the citizen- } \\
\text { assist brand } \\
\text { prospect }\end{array}$ & $\begin{array}{l}\text { Holt \& } \\
\text { Cameron 2010; } \\
\text { Luedicke, et al. } \\
\text { 2010; Torelli et } \\
\text { al. 2012; } \\
\text { Jutterstrom \& } \\
\text { Norberg 2013; } \\
\text { Andersen, et al. } \\
2019\end{array}$ \\
\hline $\begin{array}{l}\text { Sensory } \\
\text { approach }\end{array}$ & $\begin{array}{l}\text { Multisensory } \\
\text { insights }\end{array}$ & $\begin{array}{l}\text { Brands offer } \\
\text { consumers and } \\
\text { customers } \\
\text { sensory } \\
\text { experiences } \\
\text { which lead to a } \\
\text { stronger brand } \\
\text { affiliation }\end{array}$ & $\begin{array}{l}\text { Qualitative } \\
\text { methods }\end{array}$ & $\begin{array}{l}\text { in opposition to } \\
\text { the } \\
\text { information- } \\
\text { processing } \\
\text { consumer } \\
\text { perspective }\end{array}$ & $\begin{array}{l}\text { Bouzaabia } \\
\text { 2014; Hulten } \\
\text { 2015; Fajardo et } \\
\text { al. 2016; Jiang } \\
\text { et al. 2016; } \\
\text { Rahinel \& } \\
\text { Nelson 2016; } \\
\text { Krishna et al. } \\
\text { 2017; } \\
\text { Rodrigues, } \\
\text { 2018; Huang et } \\
\text { al. } 2019\end{array}$ \\
\hline
\end{tabular}

(C) 2022 by the authors. Licensee JPPD, Indonesia. This article is an open-access article distributed under the terms and conditions of the Creative Commons Attribution (CC BY) license (http://creativecommons.org/licenses/by/4.0/). 